\title{
HERITAGE TOURISM TRAIL DEVELOPMENT IN KAMPUNG LUAT, PERAK: A CASE STUDY
}

\author{
Mastura Jaafar ${ }^{* a}$ \\ Norziani Dahalan ${ }^{\mathrm{b}}$ \\ Fatimah Hassan ${ }^{\mathrm{c}}$ \\ Suhaida Herni Suffaruddin ${ }^{\mathrm{d}}$ \\ ${ }^{a, d}$ School of Housing, Building and Planning \\ Universiti Sains Malaysia, 11800 USM, Penang, Malaysia \\ ${ }^{b, c}$ School of Distance Education, Universiti Sains Malaysia \\ 11800 USM, Penang, Malaysia
}

\begin{abstract}
Kampung Luat situated in Lenggong Valley, Perak, is a well-known tourist destination due to its natural attraction, archaeological elements, promotion of rural agroindustry and home-based products, as well as unwavering and strong local community commitment. Distinct local characteristics, such as traditional culture, agricultural setup, countryside landscape, and simple lifestyles, offer a different experience for its visitors. The combination of these aspects provides a huge opportunity for tourism heritage trail development. As such, this study discusses the development of a heritage trail in Kampung Luat. The initiative was taken by a group of USM researchers, along with the cooperation from the local community. Observation and focus group discussion (FGD) techniques were adopted in this study. Several meetings were conducted and the development of Kampung Luat heritage trail was proposed, which covered seven stops in four hours, which involved 20-30 residents with different roles. This heritage trail was tested by 20 respondents. The findings showed that the visitors had placed a high value in the experience and enjoyed the different rural
\end{abstract}

\footnotetext{
*Corresponding author: masturaj@usm.my eISSN 2636-9265 (C) Centre for Civilisational Dialogue DOI: https://doi.org/10.22452/KATHA.vol15no1.4
} 
activities, apart from proposing several suggestions for trail improvement. Low level of community readiness, lack of facilities, and communication issues were their main concerns for trail improvement. These findings suggest the implementation of stringent and effective action taken by the federal and state governments, apart from including stakeholders to both coordinate and realise the heritage trail in future to increase the competitiveness at the Lenggong Valley as a tourism destination.

Keywords: Heritage trail, trail development, case study, Kampung Luat, Lenggong Valley

\section{Introduction}

Tourism has been reckoned as the largest industry in the world and has continued to grow rapidly than many other sectors (Boz, 2018). Since tourism is rapidly expanding, it has evoked interest amongst researchers on several issues, such as relevancy of products offered in relation to types of tourism, competitive advantage of destinations, and tourist quality experience. Tourist preferences have become more sophisticated and demanding due to the vast choices being offered. Competition between destinations has heightened due to the emergence of new destinations, creative marketing strategies, and striking product focus (Boz, 2018). The United Nations World Tourism Organisation (UNWTO) (2000) predicted that cultural tourism will be among the five key market segments in the future, with Boz (2018) highlighting the shift of new tourist intentions to experience various cultural settings, including religious, historical, traditional, and artistic heritage values.

According to Rifai (2014), heritage and cultural tourism is growing at an unprecedented rate. Timothy and Boyd (2006: pg1) described heritage tourism as 'one of the most important and widespread types of tourism and is among the very oldest form of tourism... and elements of world heritage have a unique place in cultural tourism'. It is vital that the routes offered for heritage tourism are attractive, interesting, and diversified (Nagy, 2012). Boz (2018) emphasised on the aims of the European Commission (2012) 
pertaining to the need for host destinations to search for new types of tourism that reflect the environment, natural and cultural heritage, as well as local traditions. Briedenhann and Wickens (2004) highlighted that the authentic experiences in areas of unexploited nature and rich in culture play a major role in stimulating social regeneration and in improving the living conditions of the rural communities across less developed countries.

A crucial aspect within the tourism domain refers to trails (Travis, 2011). Nevertheless, results from studies concerning trails in light of tourism and outdoor recreation primarily derive from the English-speaking Western countries (Godtman Kling, Fredman \& Wall-Reinius, 2017). Based on a literature review that ranged between 1970 and 2016, significant gaps were highlighted by Godtman Kling et al. (2017). The first is in terms of the number of studies, whereby studies on trails in Asia merely comprised of $7 \%$ out of the 36 countries surveyed. Most studies concentrated on North American and European countries. Second, qualitative study was an unpopular choice among researchers with only $11.3 \%$ opted for this method. Third, past studies mostly focused on the different aspects of trails, such as environmental protection, as well as trail management, planning, and design. Meanwhile, published papers that highlighted on planning and designing trails were only limited to sustainability aspect.

In regard to rural tourism in Malaysia, a number of issues tend to limit the potential development of trails. According to Liu (2006), tourism has not been well integrated in rural developmental strategies to enhance the living quality of the local communities. The lack of success observed in certain rural tourism destinations stemmed from the failure of stakeholders in addressing the strength of 'rurality', while the notion of a local destination only relied on the vague concept of accommodation provision into becoming a popular tourism spot. This landscape of tourism development limits the capacity building of the local community, hence failing to acknowledge their participation in the tourism industry.

Those being mentioned, the aim of this study is primarily to report the development of a heritage trail in Kampung Luat. This study is limited to the trail development to a heritage and rural setting, in which Kampung Luat was selected based on several 
justifications. First, the previous involvement of a group of researchers from Universiti Sains Malaysia, which initiated cottage industries, conjured the need for initiating a trail project. Second, since Kampung Luat is located in the buffer zone of UNESCO archaeological site, it serves as a good platform to spark destination competitiveness, while the third justification is that many traditional attractions related to agricultural and farming can be found in Kampung Luat. Primarily, this paper presents the preparatory work on the development of a heritage trail in Kampung Luat. The project proposed a trail with seven destinations within Kampung Luat and its vicinity. This paper contributes to the development of a rural heritage trail, specifically in an archaeological UNESCO site located in Perak, Malaysia.

\section{Rural Tourism, Local Community, Heritage Tourism, and Trail Development}

Tourism in rural areas is important to encourage regional economic development (Ibrahim, Zakariya \& Wahab, 2018). The setting of rural attractions, including traditional villages, local culture, and picturesque scenery, contribute to the uniqueness of each rural destination. Involvement of the local community may enhance the values offered and promote the local industry to the world (Amir et al., 2015). By paving a heritage trail, visitors are exposed to the rural lifestyle and culture, agricultural activities and farming, cottage industries, and other informal activities, which serve as integral elements that can generate income to the local community and the nation as a whole. It would be more impactful to the tourists if there are historical or heritage sites in the places that they visit. Akerlof and Kranton (2000) asserted that the cultural heritage concept, along with place identity, determines the economic impact on the local community. The combination of various attractions has the potential to prolong the stay of visitors, thus increasing the revenue of the community. Many authors, including Page and Getz (1997) and Greffe (1994), agreed on the need for rural tourism to cluster activities and attractions with a specific concern on developing tourism routes, ancillary services, optional activities, user-friendly 
signage, and entrepreneurial opportunity to secure businesses for the community.

Developed countries have discussed the cultural routes concept since the early 1990s (Briedenhann \& Wickens, 2004). It started in the European nation to increase awareness on its culture via travel. The activities offered throughout the travelling period had improved the socio-economic benefits of the local people. According to the Council of Europe (2002), the routes have enhanced the understanding of European values that form a complex culture, along with its societies. Similar benefits were reported in the United States (Hill \& Gibbons, 1994), Queensland (Network, 2000) and Africa (Briedenhann \& Wickens, 2004).

From the perspective of the community, Beaver (2005) identified trail as one of the touristic products that offer the needed services for its surrounding area. If effectively planned and managed, tourism trails are an effective element in the tourism process. Identified tours within specific trails provide the ability to connect different and significant sites in the destination. These sites, nonetheless, must adhere to some conditions and specifications. The trail can only succeed through solid planning and strong commitment offered by the local government and community. The involvement of many stakeholders in trail development is bound to increase the interaction and cooperation between them (Marshall, 2012) and can indirectly enhance their participation and decisionmaking skills.

Trails or routes have many versions and are created for various purposes. Timothy and Boyd (2014) claimed that trails are natural and/or human-made linear corridors set in urban or rural areas for tourists or recreationists. In the context of users, Moore and Shafer (2001, pg. 2) identified trails 'as travel routes and settings for activities and experience' for different purposes, such as relaxation, visiting cultural features, education, travel, scenic viewpoint, and inspiration.

Recreational trails are often created based on the type of activity or geographical location or type of environment (Godtman Kling et al., 2017). These trails can be categorised into five types, namely traditional backcountry trails, recreational greenways (mainly found in urban areas), multiple-use recreation trails, rail- 
trails and water trails (Moore \& Ross, 1998), and wilderness tracks (Timothy \& Boyd, 2014). In the context of this study, the wilderness track is appropriate as it is the most natural and remote type of trails located in exceptional nature areas and closely linked with cultural traditions or features.

Prideaux (2002) defined rural heritage as an attraction that operates in a specialised market that is commonly located in peripheral and remote areas. Heritage attractions in rural areas are a focus of a specific subgroup that is comprised of different profiles, when compared to other tourism attractions, such as shopping and theme parks. Richard (2000) stated that 'heritage tourism is largely concerned with the cultural legacy of the past, or the 'hard' cultural resources usually contained in old buildings, museums, monuments and landscapes or represented and interpreted in specialised 'heritage centres".

Heritage trail is a tourism product that is usually used to promote heritage destinations. Hayes and MacLeod (2007) defined heritage trails as a means of organising a visitor's experience by providing a purposeful and interpreted route that draws on the natural or cultural heritage by providing an educational experience for the visitor to enjoy. From the perspective of rural heritage development, several researchers have highlighted the importance of trails in terms of assisting in environmental conservation and visitor management (Silbergh et al., 1994), enhancing economic development by connecting interesting and specific destinations between heritage sites (Goussous \& Haddad, 2014), providing the needed services for its surrounding area (Beaver, 2005), as well as developing and marketing home-based businesses, such as traditional products and hand crafts (Goussous \& Haddad, 2014). Some advantages of trails are in terms of improving the lives of host communities, creating business opportunities, and enhancing the visitors' experience (Hayes \& MacLeod, 2007; Marschall, 2012; Oliveira et al., 2011; Rogerson, 2007; Zabbini, 2012).

MacLeod (2016) linked the importance of trails with creating place identity and increasing tourism potential in lessfrequented destinations. With good planning, collaboration, integration, and monitoring; trails would benefit both visitors and local community. He suggested that a well-planned trail can enhance 
visitor experience, apart from creating a purposeful and satisfying interpretation of a destination. The visitor's spending promotes local services and product, besides building strong networks to improve the business performance of a region.

In developing trails, MacLeod (2016) had outlined a few principles that have to be weighed in: (i) themes, (ii) associated sites, (iii) service information, and (iv) mode of transport. Each trail must have clear objectives and should focus on a theme. The site must be carefully selected to reflect the adopted theme, to ideally represent the authentic local culture or nature, and offer a range of ancillary services to visitors. The trails should be linked to each associated site. The sites must be reasonably resilient to visitation, easily accessible, safe, and well managed. Incorporating site visits to relevant museums and gallery collections, local attractions, events, and exhibitions can raise the visitors' knowledge and exploration experience of the destination. The trails need to integrate several common services, such as accommodation, transport, and catering. Apart from these, emphasis should be focused on the comprehensive information displays as they provide useful information for visitors, especially in the case of long-distance walking routes. Necessary signage, panels, and printed materials should be discreet and preferably placed on specific, strategic, and suitable structures. Timothy and Boyd (2014) pointed out on the need for rural areas to pay attention to the mode of transport for visitors to move from one location to another. Newly developed trails should consider walking, cycling or riding as their mode of transport. Visitors need to understand the environmental, socio-cultural, and economic impacts on users of trail to enhance their knowledge and experience. Developing a trail is indeed a challenging task. In light of trail development, Goussous and Haddad (2014) identified some obstacles, namely lack of financial support, shortage of proper planning decisions, uninitialized and distant location for domestic tourism, costly, lack of essential activities to indulge, and safety issues.

\section{Kampung Luat}


Kampung Luat is a village that is located in a UNESCO 'buffer zone' at the Temelong district and surrounded by five small network villages. The Kampung Luat village has a total of 740 residents with an average of $70 \%$ aged between 40 and 60 years old. The school leavers' age range totalled to 80 people with a majority of them being men. Most of the villagers are rubber-tappers and fishermen. The villagers' involvement in businesses is relatively low due to capital issues, lack of exposure, and local market dependency.

In year 2017, this village was nominated as a Smart Vision Village or Kampung Wawasan Bestari. Kampung Luat has an active community under the Village Sub-Committee or Jawatankuasa Kecil Kampung $(J K K K)$, which is further divided into several committees for women, youth, and agriculture. This community has also established an entrepreneurial organisation known as Kampung Luat Vision Village Cooperative or Koperasi Wawasan Kampung Luat (KWKL). Some of the locals are already involved in businesses related to honey production, as well as deer and shrimp farming. Other traditional skills that the community have include preparation of local cuisines and sculpting creative woodcrafts. A small number of the households are involved in the homestay business.

The trail development project is a continuation from a community-based tourism enterprise project carried out in Kampung Luat itself. The involvement of USM researchers in setting up cottage industries in Kampung Luat began in January 2017, sponsored by the Northern Corridor Implementation Authority (NCIA) and USM with cooperation from KWKL. This project has successfully initiated two significant product brandings from Kampung Luat, which are Lenggong Licious that refers to traditional food and Lenggong Valley Wood Craft that involves handicraft workshops. The following images display the tourismrelated products generated by the cottage industry. Nevertheless, since the community has been facing issues of getting the products to reach the customers, the USM team had initiated this trail project. The main objective is to attract tourists to visit Kampung Luat by highlighting three tourist destination spots that offer natural, cultural, and heritage elements. The other target outputs are (i) introducing cottage industries and home-based products to visitors, (ii) exposing the rural attractions to visitors for socio-economic 
benefits of the community, and (iii) enhancing cooperation among the local people. Figure 1 illustrates the products generated from the cottage industry under the community-based tourism enterprise project initiated in Kampung Luat.
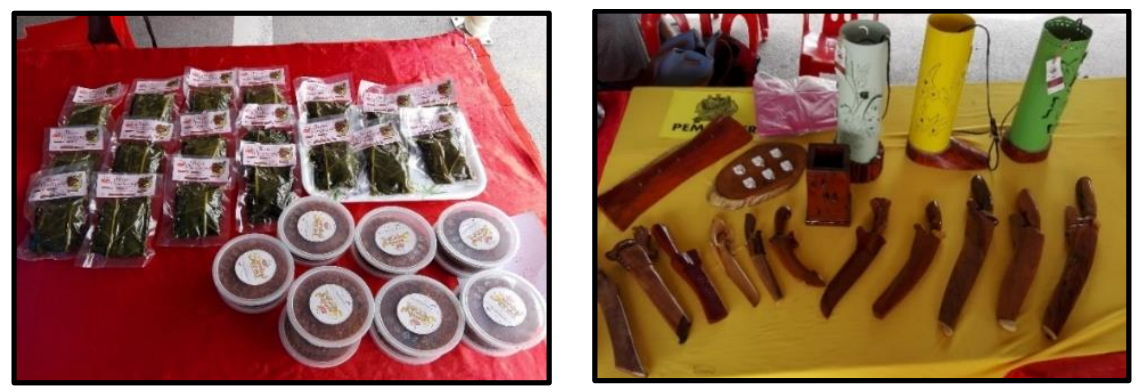

Figure 1. Products from the cottage industry: traditional food and wood craft

\section{Methodology}

\section{The development of Kampung Luat Heritage Trail}

The paving of Kampung Luat heritage trail incorporated four steps. Since two parties (USM and KWKL) were already involved in developing the cottage industry, it was easier to get USM researchers to be involved in this trail development project. The first step involved the discussions between the two parties; USM and KWKL. The discussion focused on the selection of places or stops deemed appropriate in developing the trail. The second step involved several local stakeholders, such as NCIA, Heritage Department, Lenggong District Council, and travel agency. A travel agency was invited to share its experience and knowledge on the principles of trail development and tourist needs. The third step referred to the ability of the community to present their proposed trail to the panels. This involved presentations to several related parties, including USM, local departments, and several local travel agencies. The fourth step involved testing of the proposed trail by 20 tourists from the Erasmus Mundus programme in Bangladesh, Europe, and Thailand, which was conducted on April 19th and 20th, 
2017, accompanied by several USM researchers. Figure 2 portrays the detailed activities involved in paving the trail.

\section{Step 1: January 2017}

Activity: Preliminary discussion on destination attractiveness and its related activities

Stakeholders: USM researchers and KWKL

\section{Step 2: February 2017}

Activity: Workshop on trail development by USM and travel agency. Briefing on trail development requirement, its potential, advantages and structure

Stakeholders: USM researchers, KWKL, NCIA, Lenggong District Council, tourism agency, and heritage department

\section{Steps 3: Mac 2017}

Activity: KWKL presented the proposed heritage trail of Kampung Luat

Stakeholders: USM researchers, KWKL, NCIA, Lenggong

District Council, tourism agency, and heritage department

\section{Step 4: April 2017}

Activity: Testing the heritage trail

Stakeholders: USM researchers, KWKL, local community, and 20 participants from the Erasmus Mundus programme

Figure 2. The chronology of heritage trail development in Kampung Luat

Figure 3 illustrates the details of the proposed trail journey, including the flow and the travel duration. The visitors explored the 
trail in cars due to the lengthy distance between the targeted locations. The whole trail took approximately four hours to complete.

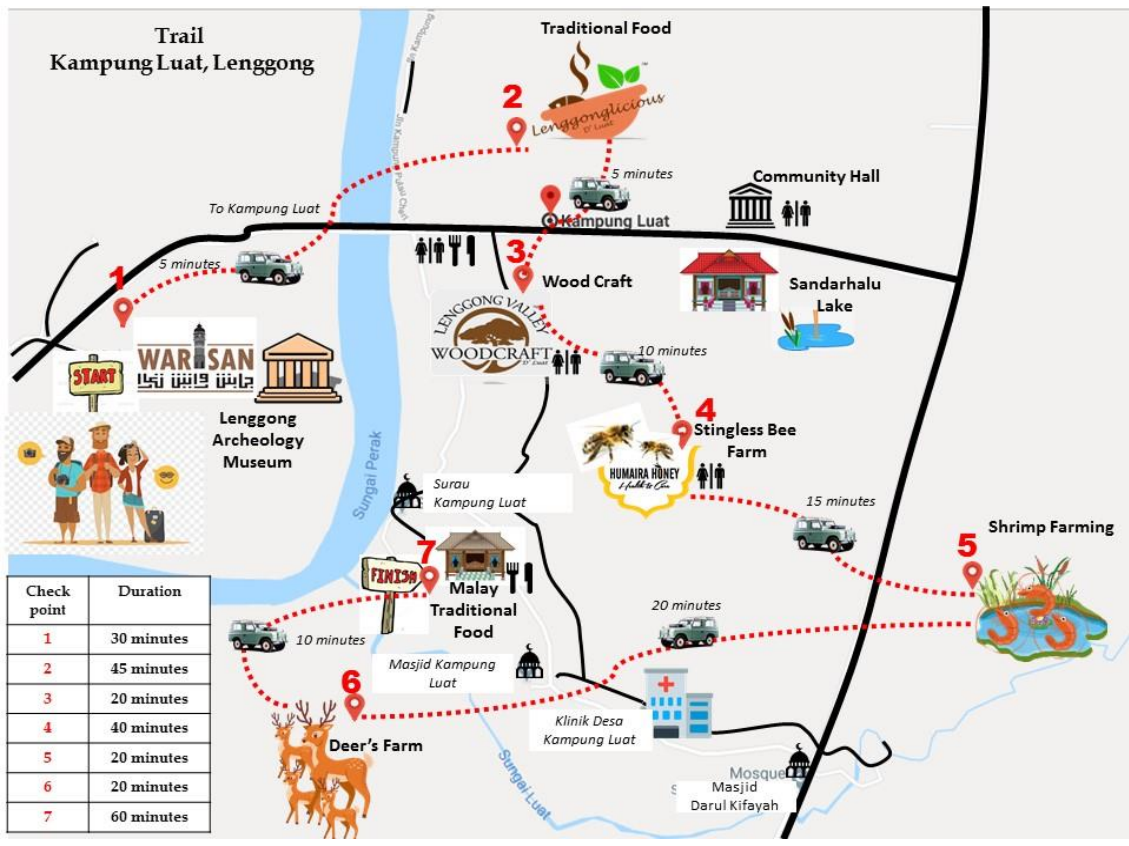

Figure 3. Graphic presentation of the flow and travel duration of the heritage trail

This trail involved sightseeing and an expedition to explore Kampung Luat, as well as its surrounding areas. The visitors were exposed to a variety of interesting activities that allowed them to experience the local culture. The trail took about four hours to be completed and it involved the following destinations:

1. The trail began at the Lenggong Archaeology Museum, where the tourists were briefed on the main archaeological history of the Perak Man. They spent some time there to look at the displayed artefacts. The information given emphasised on the journey to discover the Perak Man. 
2. A five-minute drive took them to the second destination - a home-based kitchen workshop (the first cottage industry). This workshop offered activities of preparing well-known traditional delicacies, namely ikan pindang and kebebe. These two dishes were prepared using available local ingredients. The tourists were given an opportunity to participate in the process of preparing the dishes, to taste the sumptuous local dishes, and even purchase some to bring home. The time spent in this second destination was approximately an hour.

3. Next was a visit to a local handicraft workshop to witness the production of woodcrafts from unused timber remains. Tourists could have a glimpse on how the handicrafts, such as key chains, clothes hanger, and 'keris', were made. At the end of the visit, the ready-made timber handcraft can be purchased by tourists as souvenirs.

4. Following that was a visit to the Madu Kelulut Humaira bee farm. During the visit, the tourists were briefed on the production of honey and a demonstration of the original honey extraction. At the end of the tour, tourists can purchase honey and honey-based products, such as facial soap and beauty-care sets.

5. Along the road, a lobster pond enabled the tourists to experience harvesting lobsters and grading them. They may purchase fresh lobsters there.

6. The trail ended at a deer farm. The tourists observed the breeding methods of deer and experienced memorable interactions by getting close to the domesticated deer.

7. At the end of the visit, the tourists enjoyed exquisite regional cuisines prepared from the freshest ingredients and the warm hospitality offered by the villagers.

\section{Tourist Experience in Trail Testing}

The study explored a trail development based on trial testing and focus group discussion (FGD). The FGD involved 20 participants and 5 USM researchers. The objective of the FGD was to obtain 
feedback from the trail testing. The outcomes retrieved from the FGD and feedback obtained from the participants served as the foundation to identify their experiences in trail testing. According to Lindroth, Ritalahti, and Soisalon-Soininen (2007), the main purpose of FGD is to draw upon respondents' attitudes, feelings, beliefs, experiences, and reactions towards the investigated subject. These attitudes, feelings, and beliefs may be partially independent of a group or its social setting, but are more likely to be revealed via social gathering and interaction in a FGD (Gibbs, 1997). The discussion on the feedback covered three primary aspects, namely visitor experience, satisfaction, and issues pertaining to the trail. The codes used to report the FGD results for each respondent range from $\mathrm{R} 1$ to R20. The discussion took about 40 minutes. The findings gathered from the FGD are presented in the following sub-section.

\section{Analysis and Results}

\section{Experience}

Most of the respondents stated that they had a good experience. They had a good time exploring the trail and getting the opportunity to taste authentic traditional food while enjoying the ambience of the countryside. For example, respondent R2 noted that "this is my first experience eating Malay traditional food". Meanwhile, R5 and R6 highlighted on "their first time eating using hand", and "sitting cross-legged on the floor covered with screw-pine mat". While visiting the Humaira stingless Bee Farm, they also had the opportunity to taste fresh raw honey. One of the respondents (R11) stated that, "I feel excited when I suck the honey from the hive, it tasted raw and sour but also sweet." The natural environment surrounding the trail was another experience that took their breath away. On the way back from the lobster pond, the scenery of the small river with water flowing over tiny pebbles along a bank covered with wild plants was mesmerising, as noted by R3: "Can we stop for a while? I like being here; it is so calm and beautiful." Similar responses included "I feel refreshed despite the heat." 


\section{Satisfaction}

The findings revealed the good hospitality offered by the villagers, which was both spontaneous and generous that made the tourists feel overwhelmed. One respondent (R5) stated that "of course, we'll bring our friends here." A similar respond stated "Can I get a contact name? I might come again for a backpacking trip."

Nevertheless, disappointment emerged among the respondents during the visit to the deer farm. The expression of 'disappointment' was associated with the inability to go inside the deer cage because it was locked. One respondent (R7) stated that "We could not play with the deer, and could only see them from a distance. "Lack of safety measures was another expression of disappointment voiced out during the visit to handicraft workshop". One respondent (R1), for example, noted that the worker did not wear a mask while working: "There was so much dust, it is not good for health and the workers should protect themselves by wearing masks".

\section{Issues}

i) Low level of community readiness

Upon observation, the Kampung Luat community seemed to be unready to offer a high-quality trail. They need a competent coordinator or a tourist guide to lead the trail. The USM researchers, together with the local people, played a role in training the local community on how to entertain visitors and on providing explanations at every stop of the trail. In general, the issues highlighted by the respondents (R1, R5, R7, and R11) are as follows:

\section{ii) Limited facilities}

Information signage and product information are still lacking. Basic amenities, such as public toilets, should be given more attention and properly maintained. The trail to the lobster pond and deer farm was quite dangerous and narrow due to untarred roads. 


\section{iii) Communication issues}

Not having the ability to communicate especially with foreign tourists is one major shortcoming. Most of the time, the USM researchers had to assist the villagers with the communication. The villagers also had limited knowledge on the destinations, which obstructed clear communication between the local community and the tourists. The showcased products were not specifically designed to boost sales and they were not seen as tourist attraction.

\section{Discussion and conclusion}

The growth of the tourism industry has heightened competition between destinations. Hence, each destination must be creative to strengthen its products to stay competitive in the local and global market. The demand of tourists for cultural tourism mostly benefits the rural tourism. Malaysia is blessed with a variety of natural environment settings, which add values to rural tourism. Hence, paving a trail entails the combination of archaeology, agricultural, and natural setting, as well as cottage industry and traditions, which reflect a great opportunity for the rural heritage trail in Kampung Luat. The aim of this paper is to provide an overview of a heritage trail development in Kampung Luat. This article offers new insights into trail development within the context of rural heritage tourism. A qualitative approach was employed in the trail development proposed for Kampung Luat. In view of the research gaps presented earlier, this article provides information on trail development in the context of heritage and rural setting within a typical Asian setting. Besides, the very few studies that had looked into socio-cultural or heritage recreational (Godtman Kling et al., 2017) have added value to the findings of this study. The major contribution of this paper is related to the development of a heritage trail at a UNESCO archaeological site - the Lenggong Valley.

This study identified the development of heritage trail in Kampung Luat by adhering to the guideline prescribed by MacLeod (2016), whereby the trail has its own theme in light of heritage and covered by many interesting sites in its surrounding area (as portrayed in Figure 3), whereby each site has its own specific 
information revealed to the participants. The mode of transport was the main criterion for trail development and car was selected as the main mode of transportation. Situated in rural areas, the most challenging task of the community is to overcome several obstacles highlighted by Goussous and Haddad (2014). Situated in a rural area, there are many disadvantages for Kampung Luat and the Lenggong Valley, especially in the effort to create an impact within the tourism domain. The Lenggong Valley was listed by UNESCO as a World Heritage site on $30^{\text {th }}$ June 2012, which brought in many potential products and services to be developed and realised in order to attract tourists. Unfortunately, the sought progress has been rather slow. In the attempt of addressing this pathetic scenario, a group of USM researchers took the initiative to develop a community-based tourism enterprise by utilising the strength of the local community in developing a number of traditional products of the Lenggong Valley. However, the team realised the difficulties faced by the community in terms of marketing the products, mainly due to the low number of tourists visiting the Lenggong Valley. The initiative to form a tourism trail was proposed based on several discussions held with a few stakeholders.

The trail combined a few selected elements of rural heritage, cultural, and natural attractions of Kampung Luat. The suggested trail exposed tourists to a unique combination of experience of the local archaeological asset known as the Perak Man, the cottage industry, and several farm businesses owned by the local community. The four-hour trail was only limited to the introduction of a few manufactured products of Kampung Luat. Besides, Kampung Luat and several nearby villages have many other ecotourism attractions that demand further exploration.

The opportunity to get involved with the local community of Kampung Luat offers a new insight on the improvement needed to be made in order to boost the competitive level of the Lenggong Valley. As highlighted by Liu (2006), the involvement of local community in rural tourism development calls for special attention from the related stakeholders. Rural areas have vast potentials in offering different attractiveness with the support and cooperation provided by the local community. They need to be trained to 
ascertain that that they are indeed competent in carrying out their roles, such as having the ability to communicate in different languages and providing succinct explanation in describing the products or services offered. Creativity in composing stories along the trail is definitely an added value for the trail development. Apart from exploring the natural endowments, educating tourists on the local culture can increase their mindfulness. The Rocky Mountain Institute (2001) emphasised on the need for building community capacity that is required to support the real trail development. The success of any trail highly depends on creativity, warm hospitality, and entrepreneurial skills. Similar challenges were highlighted by Briedenhann and Wickens (2004) in developing a trail in South Africa, which among all included lack of education, training, and experience in quality tourism experience or product. It would be good if both private and public agencies collaborate to take the initiative to transfer skills and expose the local community to cutting-edge technology.

By looking at other potential ecotourism attractions in Kampung Luat and its nearby villages, the real trail should be broadened to cover additional attractions, such as the waterfall, lakes, and Bukit Bunuh. These destinations can be zoned based on the activities offered. It is suggested that the Kampung Luat tourism trail to be enhanced by embedding other interesting elements and activities, such as accommodation, ecotourism, and heritage tourism. These sectors can be integrated into the local tourism, so as to create a new network of trails. Careful and deliberate selection of each destination, attention on developing suitable facilities, and good cooperation given by the community are among the major factors that demand the utmost consideration for a successful tourism trail. Providing a few trail packages would be more meaningful to a variety of tourist categories. The longer the trail, the more stops it has, and the more economic impact it will have on the local community.

In light of the rural setup of Kampung Luat, proper facilities are needed, such as public toilets, infrastructures, and communication systems, in which some require upgrade. Safety issues should be made priority to ensure a safe travel experience for tourists. According to Mnguni and Giampiccoli (2017), trail 
development should consider several practical matters, including construction of facilities, amenities, and printing (or establishing a website) of marketing materials. Again, the project should be able to tackle certain issues on upgrading infrastructures, capacity building of local people, and safe destinations. The multiple modes of transportation, such as walking, hiking/trekking, and rappelling trail, would attract the active youth community of the present day.

The uniqueness of the Lenggong Valley based on its physical and cultural assets can be strategically exploited to position Lenggong as a competitive rural archaeological destination. Success of the tourism trail offers a huge impact on the local community's economy, and the Lenggong Valley as a heritage tourism destination in Perak. The local community is the key to all developmental process, in which their participation is significant for the generation of a sustainable tourism trail.

Without doubt, the heritage tourism in Malaysia has a long way to go in achieving the integration of different destinations in a wider context. The initiatives taken by USM researchers are only a preliminary task to get the community to start thinking and learning about developing a trail. Hugo (1999) outlined the five main stages that should be incorporated in trail development, namely assessment, planning, evaluation, implementation, and monitoring/auditing. He pointed out that trail development is an uphill task and demands cooperation from many parties. Hayes and MacLeod (2008) posited that the task of paving a trail should be handled and funded by the public sector agencies.

Due to cost and time constrictions, the Kampung Luat heritage trail development, so far, has undergone its initial testing stage. This means; more efforts and work are required to enhance this trail. This paper presents only a small fraction of trail development, while its realisation seeks effective coordination between state and federal governments, as well as the collaboration between the private and public sectors. Future research may want to assess the potential to link the destinations between states or regions. Such cooperation is bound to increase the opportunity to generate higher income for many stakeholders within the tourism sector, especially the local community. 


\section{Acknowledgement}

The authors would like to extend their gratitude to the USM Industry and Community Network Division (BJIM) for funding this project.

\section{References}

Akerlof, G. A., \& Kranton, R. E. (2000). Economics and identity. The Quarterly Journal of Economics, 115(3), 715753.

Amir, A. F., Ghapar, A. A., Jamal, S. A., \& Ahmad, K. N. (2015). Sustainable tourism development: A study on community resilience for rural tourism in Malaysia. Procedia-Social and Behavioral Sciences, 168, 116-122.

Beaver, A. (2005). Dictionary of Travel and Tourism Terminology (pp. 313). USA: CABI Publishing.

Boz, M. (2018). Religious Heritage Tourism: The St. Paul Trail Project in Troas. International Journal of Religious Tourism and Pilgrimage, 6(3), 68-80.

Briedenhann, J., \& Wickens, E. (2004). Tourism routes as a tool for the economic development of rural areas-vibrant hope or impossible dream? Tourism management, 25(1), 71-79.

Council of Europe. (2002). The Europe of Cultural Cooperation. Retrieved from www.culture.coe/fr/routes/eng/eitin2.0 Retrieved 25.02.02.

European Commission. (2012). Pan-European Cultural Routes: A journey through Europe's shared cultural heritage. MEMO Brussels, 7 June 2012.

Gibbs, A. (1997). Focus groups. Social Research Update, 19(8), 18. 
Godtman Kling, K., Fredman, P., \& Wall-Reinius, S. (2017). Trails for tourism and outdoor recreation: A systematic literature review. Turizam: međunarodni znanstveno-stručni časopis, 65(4), 488-508.

Goussous, J., \& Haddad, L. G. (2014). Innovation of New Tourism Trails and its Effect on the Ajloun Touristic Process. Journal of American Science, 10(4s), 50-60.

Greffe, X. (1994). Is rural tourism a lever for economic and social development? Journal of Sustainable Tourism, 2(1-2), 2240.

Hayes, D., \& MacLeod, N. (2007). Packaging places: Designing heritage trails using an experience economy perspective to maximize visitor engagement. Journal of vacation Marketing, 13(1), 45-58.

Hill, B. J., \& Gibbons, D. (1994). Sustainable Tourism-Heritage Trails in Nebraska, Building a Sustainable World through Tourism. In Second Global Conference. Montreal, Quebec, Canada, 12 - 16 September 1994.

Hugo, M. L. (1999). A comprehensive approach towards the planning, grading and auditing of hiking trails as ecotourism products. Current Issues in Tourism, 2(2-3), 138-173.

Ibrahim, I., Zakariya, K., \& Wahab, N. A. (2018). Satellite Image Analysis along the Kuala Selangor to Sabak Bernam Rural Tourism Routes. IOP Conference Series: Earth and Environmental Science, 117(1), 1-7.

Lindroth, K., Ritalahti, J., \& Soisalon-Soininen, T. (2007). Creative tourism in destination development. Tourism Review, 62(3/4), 53-58.

Liu, A. (2006). Tourism in rural areas: Kedah, Malaysia. Tourism Management, 27(5), 878-889. 
MacLeod, N. (2016). Self-guided trails-a route to more responsible tourism? Tourism Recreation Research, 41(2), 134-144.

Marschall, S. (2012). Sustainable heritage tourism: The Inanda heritage route and the 2010 fifa world cup. Journal of Sustainable Tourism, 20(5), 721-736.

Mnguni, E. M. \& Giampiccoli, A. (2017). Community-based tourism development: a Hiking Trails perspective. African Journal of Hospitality, Tourism and Leisure, 6(1), 1-17.

Moore, R. L., \& Ross, D. T. (1998). Trails and recreational greenways: corridors of benefits. Parks \& Recreation (Ashburn), 33(1), 68-79.

Moore, R. L., \& Shafer, C. S. (2001). Introduction to special issue trails and greenways: Opportunities for planners, managers, and scholars. Journal of Park and Recreation Administration, 19(3), 1-16.

Nagy, K. (2012). Heritage tourism, thematic routes and possibilities for innovation. Club of Economics in Miskolc. TMP, 8(1), 46-53.

Network, Q. H. T. (2000). Cultural Tourism Incentive Programme 2000-2002. Brisbane: Queensland Government Department of the Premier and Cabinet.

Oliveira, S. D., Pereira, L. C. C., Vila-Concejo, A., Gorayeb, A., Sousa, R. D., \& Costa, R. D. (2011). Natural and anthropogenic impacts on a macrotidal sandy beach of the Brazilian Amazon (Ajuruteua): guidelines for coastal management. Journal of Coastal Research, 64, 1385-1389.

Page, S., \& Getz, D. (Eds.). (1997). The Business of Rural Tourism: International Perspectives (pp. 191-205). United Kingdom: Cengage Learning EMEA. 
Prideaux, B. (2002). Creating rural heritage visitor attractions-The Queensland Heritage Trails project. International Journal of Tourism Research, 4(4), 313-323.

Richards, G. (2000). Tourism and the world of culture and heritage. Tourism Recreation Research, 25(1), 9-17.

Rifai, T. (2014). Tourism: Promoting Our Common Heritage and Fostering Mutual Understanding. In. International Congress Religious Heritage and Tourism: Types, Trends and Challenges. Elche, Spain, 26-28 November 2014.

Rocky Mountain Institute (2001). Framework for Community Sustainability: Ten Ingredients for Long-Term Success, Snowmass. Colorado: Rocky Mountain Institute.

Rogerson, C. M. (2007). Tourism routes as vehicles for local economic development in South Africa: The example of the Magaliesberg Meander. Urban Forum, 18(2), 49-68.

Silbergh, D., Fladmark, J. M., Henry, G., \& Young, M. (1994). A strategy for theme trails. A Strategy for Theme Trails. (pp. 123-146). London: Donhead Publishing Ltd

Timothy, D. J., \& Boyd, S. W. (2006). Heritage tourism in the 21st century: Valued traditions and new perspectives. Journal of Heritage Tourism, 1(1), 1-16.

Timothy, D. J., \& Boyd, S. W. (2014). Tourism and Trails: Cultural, Ecological and Management Issues. United Kingdom: Channel View Publications.

Travis, A. S. (2011). Introduction to UK upland planning for countryside conservation, recreation and tourism. In Planning for Tourism, Leisure and Sustainability: International Case Studies, (pp. 122-128). Wallingford: CAB International. 
UNWTO World Tourism Organisation. (2000). Tourism 2020 Vision, World Tourism Organization, Madrid. Retrieved from

http://www.ontit.it/opencms/export/sites/default/ont/it/docu menti/archivio/files/ONT_2001-01-01_00991.pdf

Zabbini, E. (2012). Cultural routes and intangible heritage. Almatourism-Journal of Tourism, Culture and Territorial Development, 3(5), 59-80. 